\title{
PERCEIVED ENJOYMENT AND MALAYSIAN CONSUMERS' INTENTION TO USE A SINGLE PLATFORM E-PAYMENT
}

\author{
Lai Poey Chin and Zainal Ariffin Ahmad \\ College of Graduate Studies, \\ Universiti Tenaga Nasional (UNITEN), \\ 43000 Kajang, Selangor, Malaysia \\ e-mail: pcresearch8@gmail.com \\ e-mail: azainal@uniten.edu.my
}

\begin{abstract}
This study explores the perceived enjoyment of Malaysian consumers' in adopting a single platform e-payment system and the relationship between perceived ease of use, perceived usefulness and perceived enjoyment with consumers' intention to use a single platform that integrates card, internet and mobile. The online survey was conducted on respondents owning either mobile phone, card payment, or internet. Based on analysis using AMOS version 21.0, the results showed that perceived ease of use can be used as mediator of perceived enjoyment. Perceived ease of use was also found to be significant in determining perceived usefulness and consumers' intention to use the system. This finding also suggests that as consumers perceive the single platform e-payment system as highly enjoyable, easy to use and useful; they would be more ready to use thee-payment system. The results of this study bear social implications on the purchasing behavior of Malaysian consumers and how businesses conduct transactions in the future using novel, single platform e-payment system.
\end{abstract}

Key Words: Enjoyment, Consumers' Intention, Single Platform e-payment,Card, Internet, Mobile

\section{INTRODUCTION}

Consumers are attracted to e-payment technologies due to the ease of use, user friendliness, and in some instances cost savings (Kalakota and Whinston, 1996; Burdett, 1999; Schwartz, 2001, Sumanjeet, 2009). Hultman (2005) notes that the consumers are evaluating the overall quality of services offered throughout their entire experience. There has been increase of researchers study enjoyment lead to consumers' intention to use Internet services (Moon and Kim, 2001; Van der Heijden, 2003) and mobile services (Verkasalo, 2008; Phan and Diam, 2011). The encounter thus presents an opportunity to show the organization's potential as a quality service provider, and to enhance consumers' intention to use. This study focuses on the consumers-based research orientation such as consumers' intention to use that is measureable with the adoption of Technology Acceptance Model (TAM) (Davis, Bogozzi and Warshaw, 1989) to enhance the efficiency of identifying the potential of deploying an integrated e-payment single platform system with perceived enjoyment. Therefore, this study seeks to explore the perceived enjoyment of Malaysian consumers' in adopting a single platform e-payment system. Further, this study also investigate the relationship between perceived ease of use, perceived usefulness and perceived enjoyment with consumers' intention to use one single e-payment platform that integrates Card, Internet and Mobile as a novel system. 


\section{LITERATURE REVIEW}

Technology Acceptance Model (TAM) was introduced by Fred Davis in 1986 and specifically tailored for modeling users' acceptance of information systems or technologies or new product acceptance. The goal of Davis (1989) TAM is to explain the general determinants of technology acceptance that lead to explaining users' behaviour across a broad range of end-user computing technologies and user populations. The belief of the person towards a system might be influenced by other factors referred to as external variables in TAM. In this study will based on Technology Acceptance Model that was formed by Venkatesh and Davis (1996) after the main finding of both perceived usefulness and perceived ease of use were found to have a direct influence on behaviour intention, thus eliminating the need for the attitude construct. The two significant beliefs exist in the TAM are the perceived usefulness and perceived ease of use. TAM also postulates that perceived ease of use stimuli perceived usefulness because the easier to use single platform e-payment system, the more useful users perceive the single platform e-payment system to be. There are empirical studies of the TAM include this correlation and the finding share a significant relationship between these two factors (Moon and Kim, 2001; Van der Heijden, 2003; Shih, 2004).

With the emergence of technology, additional variables are introduced to the TAM so to produce an extended TAM for predicting consumers' intention to use. These variables include product involvement (Koufaris, 2002),cost (Shih, 2004) and perceived enjoyment (Sun and Zhan, 2006). The factor of perceived enjoyment is added in TAM according to Liao, Tsou, and Shu, (2008) and Cheema,Rizwan, Jalal, Durrani, Sohail(2013) studies on online shopping adoption and found that perceived enjoyment has direct relationship with intention to use. Perceived Enjoyment in this study is defined as enjoyable and exploratory as a subjective psychological experience that is the context of information technology and computer-mediated environments (Webster, Trevino, Ryan, 1993). Venkatesh (2000) expressed perceived enjoyment as the extent to which the activity of using a particular system is perceived to be enjoyable in its own right, aside from any performance consequences resulting from system use. The enjoyment on adoption intentions to use Single platform e-payment system is manifested through consumers' existing experience of using cards, Internet and Mobile that can be done on a single platform. Information System researchers start to acknowledge that how enjoyable an information system may be is as important as how usable and useful it is (Blythe, Hassenzahl, Wright, 2004). Therefore, enjoyment becomes a vital construct for this study in determining consumers' intention to use the novelty of single platform e-payment system.

Based on TAM as the underlining theory, Figure 1 demonstrates the variables used in this study to determine consumers' intention to use the single platform e-payment system. For the purpose of the study, the following hypotheses were posited:

$\mathrm{H} 1$ : Perceived enjoyment has relationship on perceived usefulness.

$\mathrm{H} 2$ : Perceived enjoyment has relationship on perceived ease of use.

H3: Perceived enjoyment is associated with consumers' intention to use

H4: Perceived usefulness is positively associated with consumers' intention to use

H5: Perceived ease of use has positive relationship on perceived usefulness.

H6: Perceived ease of use is positively associated with consumers' intention to use. 


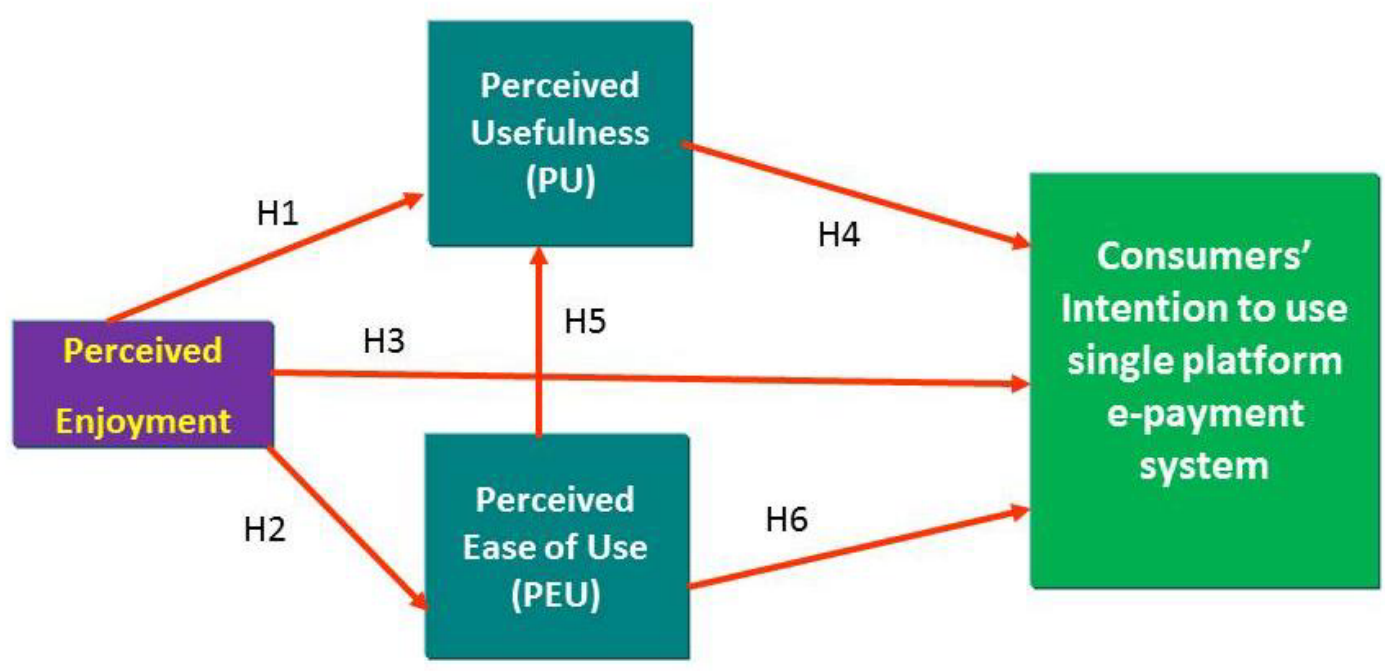

Figure 1: Theoretical Framework

\section{METHODOLOGY}

Given the Malaysia population is 28.3 million (Malaysian Census Report, 2010), the population in this study includes only respondents who have made payment either mobile phone or card or internet for last 12 months. Data collection was done via online survey questionnaire. Based on non-probability sampling, 384 samples were required (Krejcie and Morgan, 1970) which was more than 200 samples recommended for models in SEM studies(Hair, Black, Babin, Anderson andTatham, 2006; Klien, 2011). Data was collected from 389 respondents who fulfill the requirements and used in the analysis.

In this study, five-point scale Likert-type ('strongly disagree' to 'strongly agree') were used to measure the consumers' intention to use a single platform e-payment system. The five point scale was selected to encourage respondents to make positive or negative choices (Cooper, Schindler, and Sun 2008) in order to produce more emphatic information (Oppenheim, 1992). The Cronbach's alphas for the variables are as follows: consumers' intention to use (.90), perceived usefulness (.95), perceived ease of use (.95) and perceived enjoyment (.90).

\section{RESULTS}

Table 1 shows the respondents' demographic profiles of the survey. Majorityor $45.2 \%$ were in the age range of $26-40$ years old with $60.4 \%$ male respondents, single $(51.7 \%)$ with at least college/university (69.9\%) working at middle management level (42.2\%). About $62.7 \%$ owned all three (3) items mobile phone, internet and card payment. 
Table 1

Respondents' profile

\begin{tabular}{|c|c|c|}
\hline Variable & $\begin{array}{l}\text { Frequency } \\
(n=389)\end{array}$ & $\begin{array}{c}\text { Percent } \\
\text { (Total } 100 \%)\end{array}$ \\
\hline \multicolumn{3}{|l|}{ Gender } \\
\hline Male & 235 & 60.4 \\
\hline Female & 154 & 39.6 \\
\hline \multicolumn{3}{|l|}{ Marital Status } \\
\hline Single & 201 & 51.7 \\
\hline Married & 188 & 48.3 \\
\hline \multicolumn{3}{|l|}{ Age } \\
\hline$<25$ & 86 & 22.1 \\
\hline $26-40$ & 176 & 45.2 \\
\hline $41-55$ & 105 & 27.0 \\
\hline$>55$ & 22 & 5.7 \\
\hline \multicolumn{3}{|l|}{ Education } \\
\hline Secondary/High school & 60 & 15.4 \\
\hline College/university & 272 & 69.9 \\
\hline Graduate school & 54 & 13.9 \\
\hline Other & 3 & 0.8 \\
\hline \multicolumn{3}{|l|}{ Job position } \\
\hline Top Management & 27 & 6.9 \\
\hline Middle Management & 164 & 42.2 \\
\hline Junior Management & 45 & 11.6 \\
\hline Professional & 12 & 3.1 \\
\hline Other & 141 & 36.2 \\
\hline \multicolumn{3}{|l|}{ Owning } \\
\hline 1 item (Mobile/Internet/Card) & 53 & 13.6 \\
\hline $\begin{array}{l}2 \text { items(Mobile+Card/Mobile+Internet/ } \\
\text { Card+Internet) }\end{array}$ & 92 & 23.7 \\
\hline 3 items (Mobile, Internet \& Card) & 244 & 62.7 \\
\hline
\end{tabular}

\section{Measurement Model}

All the goodness of fit indices were good and satisfied the requirements with the validity assessment of the CFA model. Chi-Square was229.68 ( $p=0.00, d f=87)$. Basedon Tabachnick and Fidell (2007), the relative Chi-Square (X2/df) at 2.64 is below the 5.0 required for good fit. As stated by Hair et al. (2006), p-value is sensitive to the sample size and it may occur significant if using large sample size (Hair et al. 2006). In absolute fit indices, the goodness of fit index (GFI) was .93, higher than .90 (Hair et al. 2010). Comparative fit index (CFI) was .97, above the .90 required for good fit (Hu and Bentler, 1999). Root mean square error of approximation (RMSEA) was .064 , below the .08 required for good fit (Byrne 1998). For the overall measurement model, the results indicated good fit model. 


\section{Structural Model}

Based on the results of measurement model, the structural model was examined with the theoretical links as shown in Figure 2 with all of the goodness of fit indices that indicated an acceptable model.

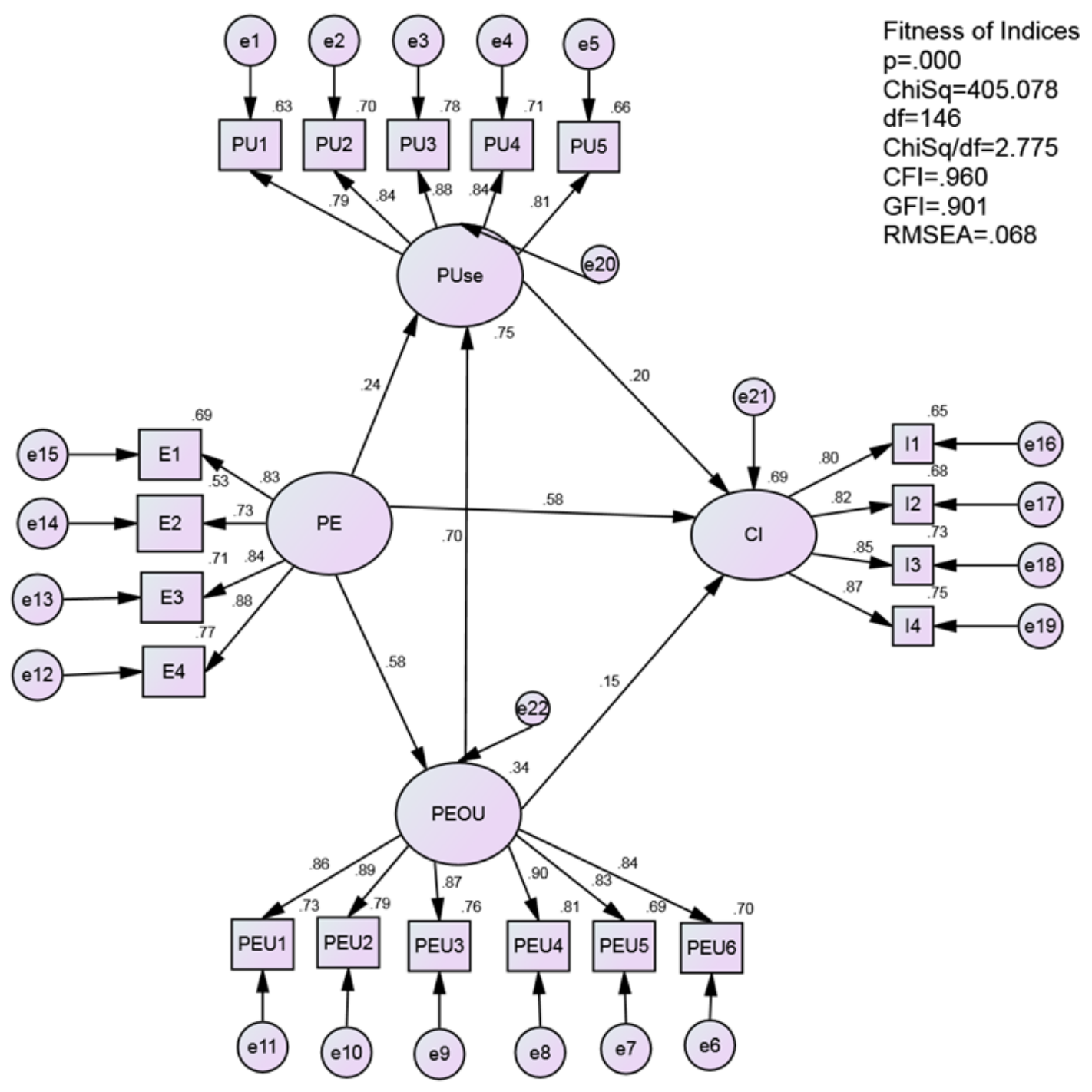

Figure 2: Structural Model

The overall structural model shows all paths of standardized regression weights as shown in Table 2 are statistically significant at the $p \leq 0.001$ and $p \leq 0.05$ level and that all the six hypotheses were supported. 
Table 2

Standardized Regression Weights of Structural Model

\begin{tabular}{|c|c|c|c|c|c|c|c|}
\hline Hypothesis & \multicolumn{3}{|c|}{ Standardized Regression Weights } & S.E. & C.R. & $\mathbf{P}$ & Results \\
\hline Hypothesis 1 & PU & $<--$ & $\mathrm{PE}$ & .036 & 5.62 & $* * *$ & Sig. $p \leq 0.001$ \\
\hline Hypothesis 2 & PEOU & $<--$ & PE & .045 & 11.21 & *** & Sig. $p \leq 0.001$ \\
\hline Hypothesis 3 & $\mathrm{Cl}$ & $<--$ & PE & .057 & 10.23 & $* * *$ & Sig. $p \leq 0.001$ \\
\hline Hypothesis 4 & $\mathrm{Cl}$ & $<--$ & PU & .100 & 2.38 & .02 & Sig. $p \leq 0.05$ \\
\hline Hypothesis 5 & PU & $<--$ & PEOU & .052 & 13.07 & $* * *$ & Sig. $p \leq 0.001$ \\
\hline Hypothesis 6 & $\mathrm{Cl}$ & $<--$ & PEOU & .087 & 2.05 & .04 & Sig. $p \leq 0.05$ \\
\hline
\end{tabular}

Note: $\quad$ PU Perceived Usefulness, PE Perceived Enjoyment, PEOU Perceived Ease of Use, $\mathrm{Cl}$ Consumer Intention, Sig. - Significant

\section{DISCUSSION AND CONCLUSION}

This study included perceived enjoyment as an exogenous factor in the technology acceptance model (Davis, 1996).SEM analysis shown a significant positive relationship between perceived ease of use and perceived usefulness and it was the strongest predictor of usefulness with path coefficient $=.70$ $(C . R=14.27, p=0.00)$ in Figure 2. Consistent with the previous studies, perceived usefulness is found to be predicted by perceived ease of use (Davis et al., 1989; Venkatesh and Davis 2000; Henderson and Divett, 2003; Wong and Teo, 2009). When consumers' perceived the single platform e-payment system is easy to use, their perception of the e-payment system is that it is useful too. Perceived enjoyment has a lower direct significant relationship with perceived usefulness (.24) than with perceived ease of use (.58). Thus, in this study perceived ease of use can be considered vital in determining perceived usefulness in complex system like the single platform e-payment system as suggested by Sun and Zhang (2006). Therefore, for complex systems like the single platform e-payment system, organizations planning to implement the system might look at perceived ease of use and may use it as the mediator to enhance perceived usefulness and consumers' intention to use.

The positive significant relationships between perceived enjoyment with perceived usefulness and perceived ease of use are supported by previous studies (Venkatesh et al., 2002; Yi and Hwang, 2003). Furthermore, the significant relationship for perceived enjoyment and consumers' intention to use the system are also supported (Agarwal and Karahanna; 2000; Van der Heijden, 2003; Shen, 2012; Cheema et al, 2013). Thus, perceived enjoyment could be mediated by both perceived usefulness and perceived ease of use as well as direct relationship on perceived consumers' intention to use the e-payment system. The results suggest that perceived usefulness contributes 20 per cent, perceived ease of use contributes 15 per cent and perceived enjoyment contributes 58 percent towards consumers' intention to use the system. Therefore, when consumers think that the single platform epayment system is highly enjoyable, easy to use and useful; they will be more ready to use the system. These findings bear social implications on the purchasing behavior of Malaysian consumers and how businesses conduct transactions in the future using the novel, single platform e-payment system.

One limitation of using online survey is the limited target audiences with Internet access only. The data also represents only the Malaysian context and might not be relevant to other countries. The data was collected at one point of time and may change over time due to greater experience and advancement of E-payment technologies. Therefore, future study should be expanded to non-internet users using traditional survey method. This study can be replicated in other developed or developing countries as well as a longitudinal study to examine the single platform e-payment system and consumers' intention to use. 
In conclusion, the empirical results from the study suggest that perceived ease of use is significant in determining perceived usefulness and consumers' intention to use the single platform epayment system. Perceived ease of use can be used as mediator of perceived enjoyment. As consumers perceive the single platform e-payment system as highly enjoyable, easy to use and useful; they would be more ready to use the e-payment system.

\section{REFERENCES}

Agarwal, R. and E. Karahanna (2000). Time flies when you're having fun: cognitive absorption and beliefs about information technology usage, MIS Quarterly. Vol (24)4, pp. 665-694.

Balasubramanian, S., Peterson, R., A. and Javenpaa, S. L. (2002). Exploring the of M-Commerce for markets and marketing, Journal of the Academy of Marketing Science, Vol. 30(4), pp. 348-361.

Biljon, J., and Kotze, P., (2007). Modelling the factors that influence mobile phone adoption. ACM International Conference Proceeding Series, 226, pp. 152-161.

Blythe, M., Hassenzahl, M. and Wright, P. (2004).More funology. Interactions, Vol. 11 (5), p. 37.

Burdett, D. (1999). The true cost of e-purse - A Mondex Perspective. European Business Review. Vol. 99 (4), pp. 265-270.

Byrne, B. M. (1998). Structural Equation Modeling with LISREL, PRELIS, and SIMPLIS: Basic Concepts, Applications, and Programming. New Jersey: Lawrence Erlbaum Associates.

Cheah, C. M., Oon K. M.,Teo A. C., Tan B. I. and Sim J. J., (2011). Factors affecting malaysian mobile banking adoption: An empirical analysis. International Journal of Network and Mobile Technologies, Vol. 2(3), pp. 149-160.

Cheema, U., Rizwan, M., Jalal, R., Durrani, F., Sohail, N., (2013).The trend of online shopping in 21st century: Impact of enjoyment in TAM Model. Asian Journal of Empirical Research. Vol. 3(2), pp. 131-141.

Cooper, D. R., and Schindler, P. S., (2008).Business Research Methods (10th ed.). New York: McGraw-Hill.

Davis, F.D., (1986). A Technology Acceptance Model For Empirically Testing New End-User Information Systems: Theory And Results. Massachusetts, United States: Sloan School of Management, Massachusetts Institute of Technology.

Davis, F. D., (1989). Perceived usefulness, perceived ease of use, and user acceptance of information technology.MIS Quarterly. Vol. 13(3), pp. 319-340.

Davis F.D., Bogozzi, R., P., and Warshaw, P., R., (1989). User acceptance of computer technology: A comparison of two theoretical models. Management Science. Vol. 35, pp. 982-1003.

Guriting, P. and Ndubisi, N., O., (2006). Borneo online banking: Evaluating customer perceptions and behavioral intention. Management Research News, Vol. 29 (1/2), pp. 6-15. 
Hair, J., Black, W., Babin, B. Y. A., Anderson, R., \& Tatham, R. (2010).Multivariate Data Analysis (7th ed.). New Jersey: Pearson Prentice Hall.

Henderson, R. and Divett., M., J., (2003). Perceived usefulness, ease of use and electronic supermarket use. International Journal of Human-Computer Studies. Vol. 59, pp. 383-395.

Hu, L., \&Bentler, P. M. (1999).Cutoff criteria for fit indexes in covariance structure analysis: Conventional criteria versus new alternatives. Structural Equation Modeling: A Multidisciplinary Journal. Vol. 6(1), pp. 1-55.

Hultman, J., (2005). The moment of truth: a key to successful services marketing. INTI Journal. Vol. $1(5)$, pp. 363-370.

Kalakota R. and Whinston, A.B., (1996).Frontiers to Electronic Commerce. Reading, MA: Addison Wesley.

Krejcie, R., and Morgan, D. W., (1970). Determining sample size for research activities.Educational and Psychological Measure. Vol. 30, pp. 607-610.

Kline, R. B., (2011). Principles And Practice Of Structural Equation Modelling (3rd ed.). New York: Guilford Press.

Koufaris, M. (2002).Applying the technology acceptance model and flow theory to online consumer behavior, Information Systems Research. Vol. 13(2), pp. 205-223.

Liao, C., Tsou, C., and Shu, Y., (2008). The roles of perceived enjoyment and price perception in determining acceptance of multimedia-on-demand. International Journal of Business and Information. Vol. 3(1), pp. 27-52.

Malaysia Census Report (2010). The 2010 Population and Housing Census of Malaysia. Retrieved 30 June 2013, from http://www.statistics.gov.my/portal/index.php?option=com_content\&view= article\&id=1215\%3Apopulation-distribution-and-basic-demographic-characteristic-reportpopulation-and-housing-census-malaysia-2010-updated-2972011\&catid=130\%3Apopulationdistribution-and-basic-demographic-characteristic-report-population-and-housing-censusmalaysia-2010\&lang=en.

Moon, J. W., and Kim, Y. G. (2001).Extending the TAM for a World-Wide-Web context. Information \& Management. Vol. 38, pp. 217-230.

Oppenheim, A.N., (1992). Questionnaire Design, Interviewing And Attitude Measurement (2nd ed.). London and New York: Continuum International Publishing.

Pagani, M., (2004).Determinants of adoption of third generation mobile multimedia services. Journal of Interactive Marketing. Vol. 18(3), pp. 46-59.

Phan, K., and Diam, T., (2011).Exploring technology acceptance for mobile services. Journal of Industrial Engineering and Management. Vol. 4(2), pp. 339-360.

Schwartz, E.I., (2001). Digital cash payoff. Technology Review. Vol. 104(10), pp. 62-68. 
Sekaran, U. (2003), Research Methods for Business: A Skill-Building Approach. 4th ed. USA: John Wiley and Sons, Inc.

Shen, J., (2012). Social comparison, social presence, and enjoyment in the acceptance of social shopping websites. Journal of Electronic Commerce Research, Vol. 13 (3), pp. 198-212.

Shih, H.P. (2004). Extended technology acceptance model of Internet utilization behaviour. Information and Management. Vol. 41(6), pp. 719-729.

Sumanjeet, S., (2009).Emergence of payment systems in the age of electronic commerce: The state of art. Global Journal of Business Research. Vol. 2(2), pp. 17- 36.

Sun, H., and Zhang, P. (2006).Causal relationships between perceived enjoyment and perceived ease of use: an alternative approach. Journal of the Association for Information Systems. Vol. 7(9), pp. 618-645.

Wheaton, B., Muthen, B., Alwin, D., F., and Summers, G. (1977). Assessing reliability and stability in panel models. Sociological Methodology.Vol. 8(1), pp. 84-136.

Tabachnick, B. G., \&Fidell, L. S. (2007). Using Multivariate Statistics. Boston: Pearson Education Inc.

Van der Heijden, H. (2003). Factors influencing the usage of websites: The case of a generic portal in the Netherlands, Information \& Management. Vol. 40(6), pp. 541-549.

Venkatesh, V. (1999) Creation of favorable user perceptions: Exploring the role of intrinsic motivation.MIS Quarterly. Vol. 23(2), pp. 239.

Venkatesh, V. and Davis, F. D., (2000).A theoretical extension of the Technology Acceptance Model: Four longitudinal field studies. Management Science. Vol. 46 (2), pp. 186-204.

Wong, S.L., \&Teo, T. (2009).Investigating the technology acceptance among student teachers in Malaysia: An application of the Technology Acceptance Model (TAM).The Asia-Pacific Education Researcher. Vol. 18(2), pp. 261-272.

Wu, J.H. and Wang S.C., (2005). What drives mobile commerce? An empirical evaluation of the revised Technology Acceptance Model. Information \& Management. Vol. 42, pp. 719-729.

Yi, M., Y., Y. Hwang, (2003).Predicting the use of web-based information systems: self-efficacy, enjoyment, learning goal orientation, and the Technology Acceptance Model. International Journal of Human-Computer Studies. Vol. 59, pp. 431-449.

Yu, J., Ha, I., Choi, M. and Rho, J., (2005).Extending the TAM for a T-Commerce. Information \& Management. Vol. 42(7), pp. 965-976. 